\title{
Extreme precipitation events in the Forest Promotion Complex of Silesian Beskid
}

\author{
Grzegorz B. Durto $₫$, Stanisław Matek ${ }^{2}$, Jarosław Socha ${ }^{3}$ \\ ${ }^{1}$ University of Agriculture in Krakow, Faculty of Forestry, Department of Forest Protection, Entomology and Forest \\ Climatology, al. 29 Listopada 46, 31-425 Kraków, Poland, phone: +48126625142, e-mail: rldurlo@cyf-kr.edu.pl \\ ${ }^{2}$ University of Agriculture in Krakow, Faculty of Forestry, Department of Forest Ecology, al. 29 Listopada 46, \\ 31-425 Kraków, Poland \\ ${ }^{3}$ University of Agriculture in Krakow, Faculty of Forestry, Department of Forest Dendrometry, al. 29 Listopada 46, \\ 31-425 Kraków, Poland
}

\begin{abstract}
An increase in frequency of weather phenomena in the Western Beskids that are disadvantageous for natural environment caused an upset of ecologic balance, especially within the scope of water management and retention. Concerns referring to forest groups maintaining their stability are fully justified, regarding that in many areas of the Beskids, there is an intensive reconstruction of stands of trees in the lower subalpine region. In turn, young generations of trees are continuously stresses, which arise from periodic shortages of precipitation within the course of the whole vegetation process. The presented work encompasses characteristics of extreme rainfall events that might have a negative impact on growth and development of Norway spruce stands in the Silesian Beskid in recent decades.

The article makes use of meteorological data from a multiannual period (1951-2010), gathered in 26 meteorological stations of the Polish Institute of Meteorology and Water Management (IMGW) in Silesian Beskid one station located in the Carpathian regional gene bank and two under canopy posts located in Wisła forestry inspectorate area. Special attention was devoted to the presence of extreme phenomena and their repeatability. The analysis of parameters of rainfall sequences was complemented with indexes determining ecological requirements of spruce, such as: Schmuck moisture indicator, Vogel-Daniels habitat dryness index and abundance of rainfall indicator developed in this study.

Results of climatological analysis confirmed that weather phenomena with, especially dynamic course may lead to destabilisation of even a properly formed and adequately developed forest ecosystem, and as a consequence, disturb stability in the natural environment. Diminishment of the index of precipitation size, which has been observed in recent years, may be one of the most crucial causes that limit the number of spruces in the stands of trees of the lower subalpine region in Silesian Beskid. The climatological analysis confirmed that during 60 years in Silesian Beskid, there were over 20 extreme weather (precipitation) episodes of different courses, intensity and surface reach, out of which at least 9 played a key role in lowering the health condition of the trees, as a consequence, it influenced destabilisation of the spruce stands in the lower subalpine region, regardless of their age or location within the area.
\end{abstract}

\section{KeY WORDS}

rainfall, drought, flood, rime, spruce forest, Western Carpathians 


\section{INTRODUCTION}

The problem of influence of extreme precipitation phenomena on natural environment is currently the centre of foresters' attention. An increase of interest in the climate results mainly from the fact that disastrous phenomena appeared in those forest lands where they were not observed before or were recorded very rarely. History of recent years confirms that deficiencies in soil and atmospheric moisture, caused by a period of dry weather without precipitation lasting several dozen days, constitute one of the main causes of distortion of water management of forest ecosystems (Archaux and Volters 2006; Bréda et al. 2006). Symptoms of the distortions are observed in the case of tree stands of various age classes, growing in various habitats, independently of their general health conditions and the manner of development. According to ecologists and foresters, these problems pose one of the main reasons of losing stability by spruce stands in Silesian Beskid (Barszcz et al. 2009; Małek 2010; Młynarczyk et al. 2011; Durło 2010b, 2011, 2012b). Symptoms of weakening of tree stands in western Beskids, observed from the middle of 1990s, with simultaneous increase in the frequency of the presence of extreme weather phenomena, caused distortion of ecological balance, mainly in the scope of water management of forest, which caused gradual deterioration of health condition of trees, in some regions even necrobiosis of forests on extended areas (Rykowski 2003; Holuša 2004; Dubrovsky et al. 2005; Durský et al. 2006; Barszcz and Małek 2008; Szabla 2009, 2011; Durło 2012b). Concerns regarding maintenance of stability by forest ecosystem seem to be more justified, taking into account that in numerous regions of Beskids, there is intensive transformation of lower subalpine forests, and an increase of a young generation is continuously influenced by stress arising from periodic deficiencies of precipitation during vegetation. The work presents characteristics of pluvial climate, which has formed vegetation conditions for spruce stands in Silesian Beskid for decades. One of the main hypotheses assumes that distortions of water management in forest ecosystems, caused by the high level of changeability of pluvial conditions and lowering of precipitation, supported a decrease in the health condition of tree stands in the lower and medium subalpine level in this part of western Carpathians.

\section{Study AREA}

The Silesian Beskid belongs to the region of western Beskid, posing as part of external western Carpathians (Kondracki 1980; Durło 2012a). This land occupies an area of about $700 \mathrm{~km}^{2}$, and creates a compact mountain group. It encompasses ranges made from Godula and Istebna sandstones. It is distinguished with narrow ridges and deep valleys, with a course similar to the longitudinal. This embraces two main ranges separated with the Vistula valley. The Stożek and Czantoria ranges as well as the Vistula range. The Silesian Beskid is characterised by a significant level of forestation rate: tree stands occupy almost $63 \%$ of the territory, out of which, $73 \%$ is constituted by coniferous forests. Mountain habitats dominate on the researched area (95\%), only $5 \%$ is occupied by upland environments. The main types of forest habitats embrace: mountain mixed forests 40 , mountain forests 41 , fresh forests 11 and mixed mountain coniferous forests $8 \%$. Tree stands growing in such conditions are first of all composed of spruce $(74 \%)$, beech $(11 \%)$, pine $(3,5 \%)$, oak $(3 \%)$ and fir (0.5\%). Forests of the Silesian Beskid play water, soil and air protection functions (Troll 1995; Kozak et al. 1999; Feliksik and Durło 2004; Durło 2012b).

The Silesian Beskid is located in the Carpathian climatic zone, in moderate climate, shaped under influence of polar and sea air masses. This area belongs to the Carpathian region, western Carpathian subregion with features characteristic for climate of mediumsized mountains (Wiszniewski and Chełchowski 1975; Okołowicz and Martyn 1979). This region is divided into three climatic levels: moderately warm, moderately cool and cool, and three precipitation levels: moist, highly moist and extremely moist. The average longterm precipitation sum in the lower subalpine level of Silesian Beskid is $1300 \mathrm{~mm}$ with deviation of $182 \mathrm{~mm}$, and it is one of the highest in Poland (Durło 2010a; 2012a, b).

\section{MAterial AND MEthOdS}

The work makes use of meteorological data from the multiannual period of 1951-2010, collected on 26 meteorological stations and posts of the institute of meteorology and water management in the Silesian 
Beskid, data from one post in Wyrchadeczka forest district, and two under the canopy located in the Vistula forest division, in the Istebna area (fig. 1, tab. 1).

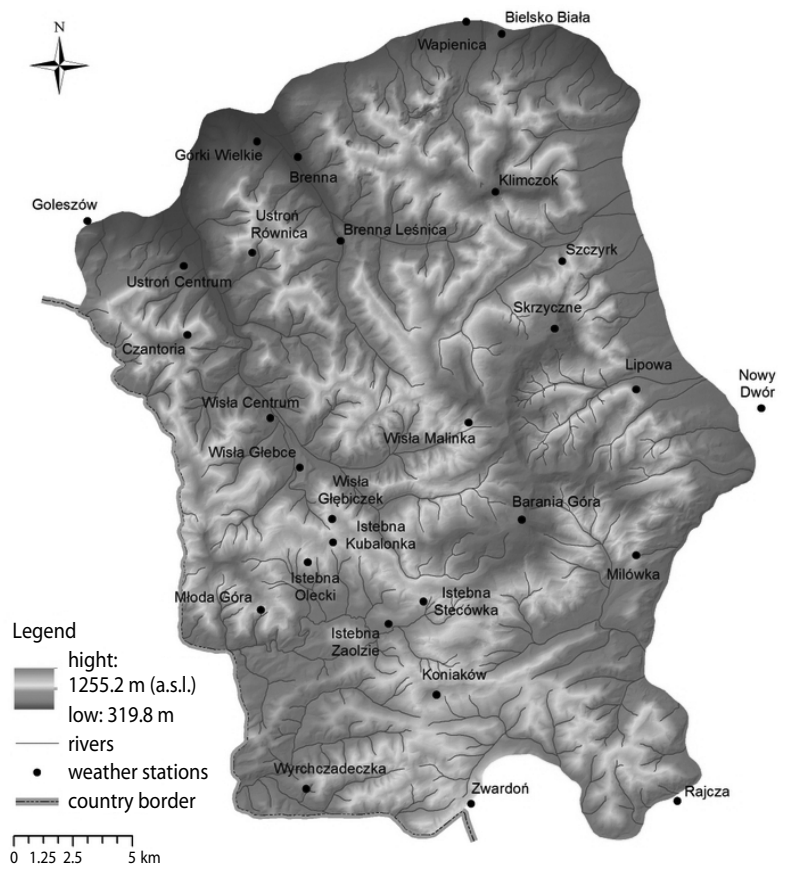

Figure 1. Map of study area with localisation of weather station

Table 1. The characteristics of meteorological stations on study area

\begin{tabular}{|c|l|c|c|c|}
\hline No. & \multicolumn{1}{|c|}{ Localisation } & $\begin{array}{c}\text { Altitude } \\
{[\mathrm{m} \text { a.s.1.] }}\end{array}$ & $\begin{array}{c}\text { Geographical } \\
\text { coordinates }\end{array}$ & $\begin{array}{c}\text { Land- } \\
\text { form }\end{array}$ \\
\hline 1 & \multicolumn{1}{|c|}{2} & 3 & 4 & 5 \\
\hline 1 & Skrzyczne & 1252 & $49^{\circ} 41^{\prime} \mathrm{N} 19^{\circ} 02^{\prime} \mathrm{E}$ & Convex \\
\hline 2 & Barania Góra & 1120 & $49^{\circ} 36^{\prime} \mathrm{N} 19^{\circ} 00^{\prime} \mathrm{E}$ & Convex \\
\hline 3 & Klimczok & 1010 & $49^{\circ} 44^{\prime} \mathrm{N} 19^{\circ} 00^{\prime} \mathrm{E}$ & Convex \\
\hline 4 & Czantoria & 852 & $49^{\circ} 41^{\prime} \mathrm{N} 18^{\circ} 49^{\prime} \mathrm{E}$ & Convex \\
\hline 5 & Młoda Góra & 820 & $49^{\circ} 35^{\prime} \mathrm{N} 18^{\circ} 52^{\prime} \mathrm{E}$ & Convex \\
\hline 6 & Istebna Kubalonka & 780 & $49^{\circ} 36^{\prime} \mathrm{N} 18^{\circ} 54^{\prime} \mathrm{E}$ & Convex \\
\hline 7 & Istebna Stecówka & 750 & $49^{\circ} 35^{\prime} \mathrm{N} 18^{\circ} 57^{\prime} \mathrm{E}$ & Convex \\
\hline 8 & Koniaków & 740 & $49^{\circ} 33^{\prime} \mathrm{N} 18^{\circ} 58^{\prime} \mathrm{E}$ & Convex \\
\hline 9 & Istebna Olecki* & 730 & $49^{\circ} 34^{\prime} \mathrm{N} 18^{\circ} 52^{\prime} \mathrm{E}$ & Convex \\
\hline 10 & Wisła Głębiczek* & 708 & $49^{\circ} 36^{\prime} \mathrm{N} 18^{\circ} 53^{\prime} \mathrm{E}$ & Convex \\
\hline 11 & Zwardoń & 690 & $49^{\circ} 30^{\prime} \mathrm{N} 18^{\circ} 59^{\prime} \mathrm{E}$ & Convex \\
\hline 12 & Wisła Malinka & 685 & $49^{\circ} 39^{\prime} \mathrm{N} 18^{\circ} 59^{\prime} \mathrm{E}$ & Convex \\
\hline 13 & Wyrchczadeczka & 675 & $49^{\circ} 32^{\prime} \mathrm{N} 18^{\circ} 55^{\prime} \mathrm{E}$ & Convex \\
\hline 14 & Ustroń Równica & 650 & $49^{\circ} 43^{\prime} \mathrm{N} 18^{\circ} 51^{\prime} \mathrm{E}$ & Convex \\
\hline 15 & Istebna Zaolzie & 580 & $49^{\circ} 34^{\prime} \mathrm{N} 18^{\circ} 56^{\prime} \mathrm{E}$ & Concave \\
\hline
\end{tabular}

\begin{tabular}{|c|l|c|c|c|}
\hline 1 & \multicolumn{1}{|c|}{2} & 3 & 4 & 5 \\
\hline 16 & Lipowa & 530 & $49^{\circ} 40^{\prime} \mathrm{N} 19^{\circ} 05^{\prime} \mathrm{E}$ & Concave \\
\hline 17 & Szczyrk & 520 & $49^{\circ} 43^{\prime} \mathrm{N} 19^{\circ} 02^{\prime} \mathrm{E}$ & Concave \\
\hline 18 & Rajcza & 495 & $49^{\circ} 40^{\prime} \mathrm{N} 19^{\circ} 10^{\prime} \mathrm{E}$ & Concave \\
\hline 19 & Wisła Głębce & 480 & $49^{\circ} 38^{\prime} \mathrm{N} 18^{\circ} 53^{\prime} \mathrm{E}$ & Concave \\
\hline 20 & Milówka & 445 & $49^{\circ} 34^{\prime} \mathrm{N} 19^{\circ} 05^{\prime} \mathrm{E}$ & Concave \\
\hline 21 & Wisła Centrum & 430 & $49^{\circ} 39^{\prime} \mathrm{N} 18^{\circ} 52^{\prime} \mathrm{E}$ & Concave \\
\hline 22 & Brenna Leśnica & 420 & $49^{\circ} 43^{\prime} \mathrm{N} 18^{\circ} 54^{\prime} \mathrm{E}$ & Concave \\
\hline 23 & Ustroń Centrum & 410 & $49^{\circ} 43^{\prime} \mathrm{N} 18^{\circ} 49^{\prime} \mathrm{E}$ & Concave \\
\hline 24 & Bielsko-Biała & 398 & $49^{\circ} 48^{\prime} \mathrm{N} 19^{\circ} 00^{\prime} \mathrm{E}$ & Concave \\
\hline 25 & Wapienica & 390 & $49^{\circ} 48^{\prime} \mathrm{N} 18^{\circ} 59^{\prime} \mathrm{E}$ & Concave \\
\hline 26 & Nowy Dwór & 380 & $49^{\circ} 39^{\prime} \mathrm{N} 19^{\circ} 10^{\prime} \mathrm{E}$ & Concave \\
\hline 27 & Brenna & 350 & $49^{\circ} 45^{\prime} \mathrm{N} 18^{\circ} 52^{\prime} \mathrm{E}$ & Concave \\
\hline 28 & Goleszów & 350 & $49^{\circ} 44^{\prime} \mathrm{N} 18^{\circ} 45^{\prime} \mathrm{E}$ & Concave \\
\hline 29 & Górki Wielkie & 325 & $49^{\circ} 46^{\prime} \mathrm{N} 18^{\circ} 51^{\prime} \mathrm{E}$ & Concave \\
\hline
\end{tabular}

* under forest canopy.

The analysis was applied to the material included in the meteorological, climatological and synoptic logbooks, in month lists of observations, precipitation annual reports and strips from pluviographs and text files from recorders of automatic rain gauges (Durło 2011, 2012a). More than 600,000 of day data, 250,000 of hour data and almost a million of data from automatic recorders were taken into consideration (10-minute sums). The work puts special attention on appearance of extreme phenomena (Chomicz 1951; Cebulak and Niedźwiedź 1998; Durło 2012b). The analysis of data was conducted by application of traditional probability statements. The repeatability of extreme phenomena and probability of their appearance was evaluated on the basis of statistical distributions (Luszniewicz and Słaby 2003). Climatological indicators such as - volume of precipitation, indicator of dryness of the habitats for spruce by Vogel-Daniels and the moisture coefficient by Schmuck, including an important component that characterises the relation of the sum of precipitation of a warm and a cool semi-annum - were considered as, especially significant for analysis of pluvial conditions (Hess 1965; Modrzyński 1998; Majewski et al. 2010; Durło 2011, 2012b). The classification criteria for extreme phenomena were expanded outside the climatic standards, taking into account ecologic requirements of spruce in relation to precipitation and hygric conditions described in works of Lauscher (1976), Obmiński (1977), Myczkowski (1978) and Modrzyński (1998). 


\section{Results}

When compared to a climatic norm $(1300 \mathrm{~mm})$, the multiannual period of 1951-2010 in the Silesian Beskid can be divided into three clear precipitation periods. The first one, 1951-1970, characterised by a constant increase of the annual sum of precipitation with a culmination point in 1966-1968. However, this period was not deprived of unique events, which needed to embrace significant deficiencies in precipitation in autumn 1961. The second period since 1971 has commenced a series lasting for several dozen years, with an expressly negative trend of precipitation, reaching its minimum point in 1992 and 1993. In that time, the precipitation in the vegetation season reached $65 \%$ of the norm, and in the May-June quarter, it was only $45 \%$. It is estimated that in the lower subalpine level, the deficits of precipitation reached then from 750,000 to $800,000 \mathrm{l} / \mathrm{ha}$ per month. In the critical period, that is, 1990-1993, quotient of the sum of precipitation to the number of days with precipitation in the months of warm part of the year was less than $3 \mathrm{~mm} /$ day (tab. 2).

The moisture coefficient of Schmuck reached a dangerously low value, that is, 300. Even in the highest locations, on Stożek, Skrzyczne and Barania mountains, similar situations were recorded. From the middle of 1960s, the coefficient of precipitation volume in the vegetation period was constantly decreasing, and reached the value of $5.0 \mathrm{~mm} /$ day between 1990 and 1995, which constituted $57 \%$ of the multiannual norm (fig. 2).

Table 2. Rain abundance ratio in Silesian Beskid represented by the data from Istebna Kubalonka weather station (780 m a.s.1.), 1951-2010

\begin{tabular}{|l|c|c|c|c|}
\hline \multicolumn{1}{|c|}{ Month } & Average & $\begin{array}{c}\text { Standard } \\
\text { deviation }\end{array}$ & $\begin{array}{c}\text { Maximum } \\
\text { value }\end{array}$ & $\begin{array}{c}\text { Minimum } \\
\text { value }\end{array}$ \\
\hline January & 5.4 & 2.4 & 17.1 & 1.3 \\
\hline February & 5.1 & 2.0 & 9.7 & 1.7 \\
\hline March & 4.9 & 2.0 & 11.0 & 1.1 \\
\hline April & 5.3 & 1.8 & 9.4 & 1.8 \\
\hline May & 6.9 & 2.2 & 13.2 & 2.3 \\
\hline June & 9.0 & 2.9 & 17.5 & 3.3 \\
\hline July & 10.0 & 4.3 & 22.9 & 4.3 \\
\hline August & 8.7 & 3.9 & 19.8 & 2.8 \\
\hline September & 7.2 & 3.0 & 14.6 & 1.6 \\
\hline October & 5.3 & 2.0 & 10.0 & 1.8 \\
\hline November & 5.6 & 2.0 & 11.2 & 2.6 \\
\hline December & 5.4 & 2.5 & 13.8 & 1.8 \\
\hline
\end{tabular}

In turn, the moist coefficient demonstrated a significant decrease from 1973 to 1993 in relation to the average, usually by more than $25 \%$, and in particular years, it was even $60 \%$. Analysis of the coefficient of habitat dryness of Vogel-Daniels confirmed that

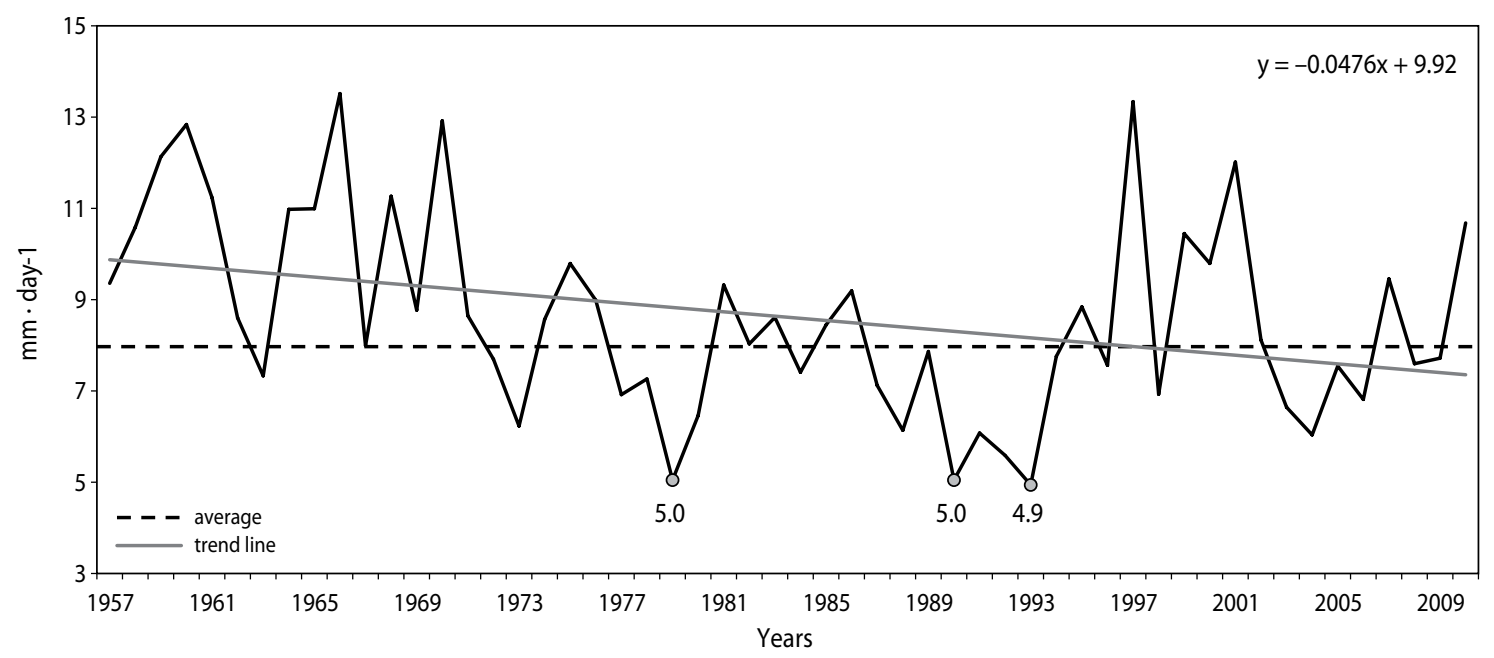

Figure 2. Multiannual course of rain abundance ratio in Silesian Beskid on example at Istebna Kubalonka meteorological station during 1951-2010 


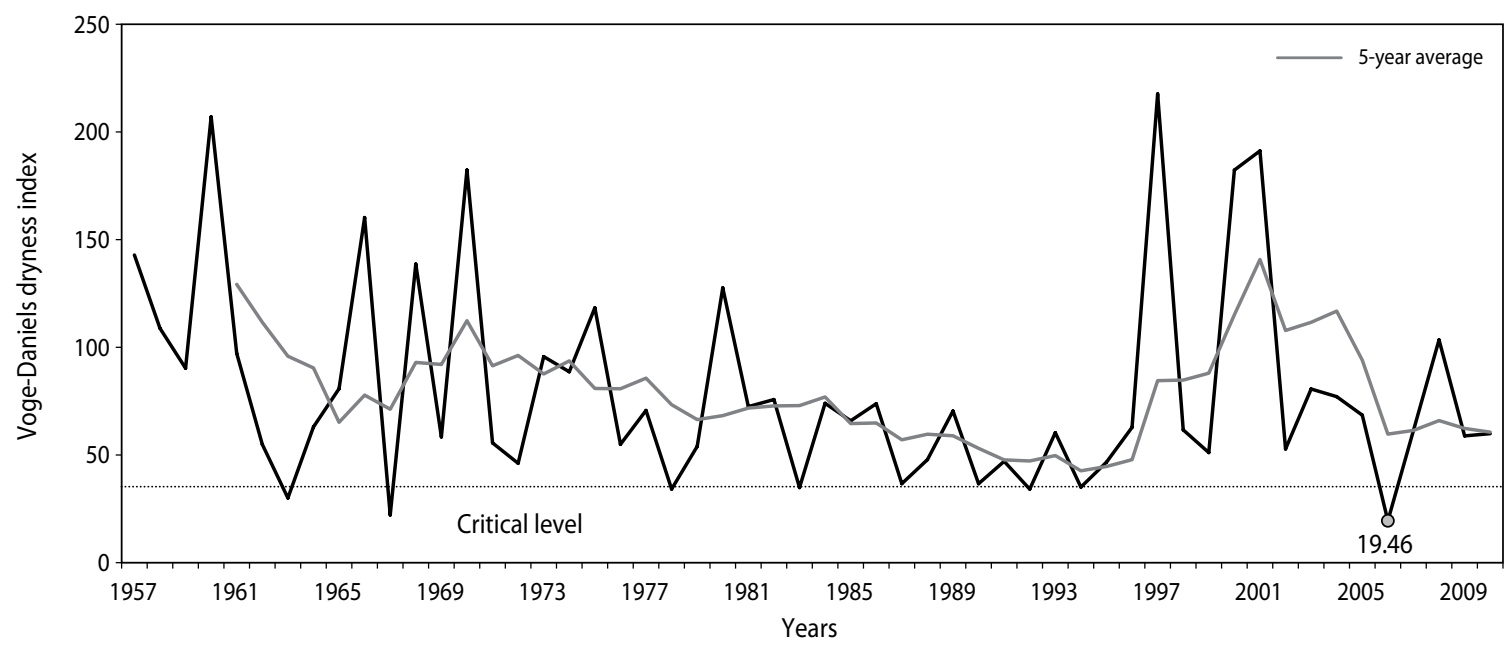

Figure 3. Multiannual course of Vogel-Daniels habitat dryness index in Silesian Beskid on example at Istebna Kubalonka meteorological station during 1951-2010

during the crucial period for spruce vegetation, pluvialthermal conditions worsened radically. Between the years 1983-1994, the index adopted critically low values 5 times (fig. 3). The same indicator reached the value of 19.5 , unseen in the history of instrumental measurements, in 2006 (fig. 3). This year was considered by forester as catastrophic in relation to weather conditions, and according to them, it decided about a situation of spruce stands in this territory.

Another precipitation period, comprising two last decades, has been a time when unusual dynamics of pluvial phenomena showed itself with above average character. At that time, very high daily, monthly and seasonal precipitation levels were recorded, for example, in 1997 and 2000, 2001 and 2010, as well as unusually low values as in 1993, 2003, 2006 and 2008. In May 1993, the ratio of precipitation level to the number of days with precipitation was only 2.3; in August 2003, only 2.8; in June 2003, $3.3 \mathrm{~mm}$ /day. Deficiency of precipitation during summer 2003 was so intense that its consequences influenced all species of forest trees present in the researched area. The deficit of water in the environment was most strongly reflected on the health condition of spruce stands. Both in 2003 and 2004 , in almost all age classes, there presented an intensified process of defoliation, as well as an increase in the number of dying trees that in some regions covered $30 \%$ of spruce population. Also, the moist coefficient by Schmuck confirmed adverse changes in the arrange- ment of pluvial conditions in recent years, it regards both imbalance of proportions between precipitation in the warm and cold part of year, and high changeability of weather in subsequent years. In the period between 1996 and 2010, there were such situations that moisture conditions changed even by several classes. The statistical analysis of distribution of both indicators points to a clear increase of probability of appearance of extremely adverse pluvial conditions and a probable growth in changeability in precipitation in the future (tab. 3).

Table 3. Relative frequency of climatic indices within the selected humidity criterion in Silesian Beskid, 1951-2010

\begin{tabular}{|l|c|c|c|}
\hline \multirow{2}{*}{\multicolumn{1}{|c|}{ Climatic indices }} & \multicolumn{3}{|c|}{ Frequency \% } \\
\cline { 2 - 5 } & $\begin{array}{c}\text { Extremely } \\
\text { dry }\end{array}$ & $\begin{array}{c}\text { Very } \\
\text { dry }\end{array}$ & Dry \\
\hline Abundance of rainfall & 0.00 & 9.95 & 17.11 \\
\hline Schmuck's aridity index & 0.00 & 1.81 & 12.25 \\
\hline Vogel-Daniels dryness index & 1.96 & 14.45 & 26.97 \\
\hline
\end{tabular}

Results of measurements in spruce stands in the Istebna region confirmed that reduction of precipitation in relation to records from the open space, was in some cases almost $40 \%$. The coefficient of precipitation volume in the forest did not reach more than $2.7 \mathrm{~mm} /$ day, when compared to the multiannual average that was more than 8 . This disadvantageous arrangement of pluvial conditions in the summer period was comple- 
mented by deficits of precipitation in the autumn period in 2005, 2008, and 2012, which resulted in a decrease of underground feeding and hydrological drought. This series of extreme phenomena in the recent time is complemented by caps of snow and hoar frosts bothering tree stands in the lower subalpine level. In addition, the time of exposure increased; in 2010, this sediment was present for more than 10 days (tab. 4).

Table 4. Extreme pluvial events in Silesian Beskid, 1951-2010

\begin{tabular}{|c|c|l|}
\hline No. & $\begin{array}{c}\text { Kind of } \\
\text { phenomenon }\end{array}$ & \multicolumn{1}{c|}{ Date of occurrence } \\
\hline 1. & Rime & $\begin{array}{l}\text { XII 1967, XII 1974, XI 1981, } \\
\text { XII 1986, XII 2005, I 2007, I 2010 }\end{array}$ \\
\hline 2. & Flood & $\begin{array}{l}\text { VII 1960, VII 1970, V 1962, VI 1968, } \\
\text { VIII 1972, VII 1997, V 2010 }\end{array}$ \\
\hline 3. & Drought & $\begin{array}{l}\text { IX 1961, VIII 1962, IX 1969, } \\
\text { VIII 1983, VIII 1992, VIII 2003, } \\
\text { VII 2006, IV 2009 }\end{array}$ \\
\hline
\end{tabular}

Heavy rains and microbursts adverse effects by way of delivery of high volumes of water to the environment, are not always reflected in soil retention within mountain areas. The microbursts more often satisfy requirements of trees only for a short period, what is more they cause erosion phenomena. In the researched period (1951-2010), the heavy rains of $4^{\text {th }}$ degree were present a dozen or so times, and driving rains of $5^{\text {th }}$ grade several times. The highest daily precipitations were recorded at the beginning of the third decade of July 1960, in the last days of the second decade of July 1970, between 20th and 22nd August 1972, 7-8 August 1985, 7-8 September 1996, in the first decade of July 1997. Similar cases were reported in subsequent years, with untypical regularity in the summer of 1998, 1999, 2000, 2001 and in 2002 and 2003, then 2 times, in 2007 and lately in 2010. A period 1996-2002 turned out to be special in this respect. Within 8 years, there were 15 cases of daily precipitation above $70 \mathrm{~mm}$ recorded. Record precipitation to the level of $224 \mathrm{~mm}$ was registered in Szczyrk on 18th July 1970. Precipitation above $200 \mathrm{~mm}$ was registered on that date in several other stations. In turn, on 21st August 1972, there was precipitation to the level of $205 \mathrm{~mm}$ on Równica mountain range. The latter was characterised by an efficiency coefficient by Chomicz between 5.8 and 6.5. Consequences of flood in 1970, 1997 and 2010 were observed in the form of ground masses movements on slopes with inclination higher than $20^{\circ}$. In 1997 and 2010, apart from damages in forests, there were also numerous damages on the surface of crops and seedling nurseries and infrastructure recorded. A very dangerous situation took place in November 2004, when after precipitation lasting 15 days, as a result of hurricane wind, tree stands in the area of 900 ha became damaged. Such a situation took place, among others, in the Zapowiedź forest district located in the Wisła forest division. In the lower parts of slopes of Czadeczka drainage basin, within a territory relatively well covered from wind, there were damages in healthy and stable spruce stands of the 3rd and 4th age class recorded. Softening of upper layers of soils caused serious damages to mechanical stability of trees, therefore leading to a radical increase in proneness of falling over. Unfortunately, in spring 2010, similar phenomena posed the cause of losses in tree stands in the Wegierska Górka forest division.

Within the course of 60 years, there were jointly 22 extreme precipitation events recorded, out of which at least 9 played a key role in decreasing stability of spruce stands in the Silesian Beskid. The remaining cases, although not so spectacular, also supported imbalance of forest ecosystem water management, and significantly influenced source of the forest spiral disease in the researched area.

\section{Discussion}

Transformation of climatic conditions within recent several dozens years, was decided by modification of the character of atmospheric circulation, mainly in second half of the 20th century. Already, at the end of 1980s, there was an increase in frequency of pressure systems observed, responsible for elevation of participation of extreme phenomena in spring and summer periods. Migała (2005) highlights that this state of affairs depends on cyclonal situations dominated by advection of air from the south-west direction. Within the scope of pluvial climate, a significant role is ascribed to the high-pressure system in the form of a ridge in latitudinal axis, forming a braid frontal zone over the central Europe. This system is responsible for lowering the sum of precipitation in spring and summer (Styszyńska 2002; Bąkowski and Piotrowicz 2007). The indicators obtained in the work confirm the 
unsettling signals coming from national and European centres of research over climate. Numerous studies present a view that the forecast sums of precipitation for the vegetation period will be at least $8 \%$ lower than in 1960 s and 1970s. These results are not optimistic when we take into account habitat requirements of spruce in this climatic zone (Lausher 1976; Obmiński 1977). Quotient of precipitation of summer period in relation to the cold half of year seems even more unsettling. Not so long ago, this indicator was 1.66; currently, it remains on the level of about 1.4 and its further decrease would influence imbalance of forest ecosystems water management in this part of western Beskids (Holuša 2004; Socha and Durło 2012). Reduction of precipitation in the summer period, significantly influenced evaluation of the moisture condition of the habitat, the indexes of which have deteriorated significantly in recent years. The multiannual course of the vog indicator presented in this work, confirms this trend, and at the same time, corresponds well with European Drought Observatory (EDO) reports. A complex evaluation of this situation was demonstrated among others by Gegor Gregorič and Stefan Niemeyer on the meeting within the BALWOIS project in 2010 in Ohrid, Macedonia (http://balwois.com/conference-/balwois-2012).

In the second half of 20th century, there were a series of situations, which could significantly influence deterioration of the health conditions of trees and loss of stability by spruce stands in the Silesian Beskid. The size of damages caused by the abiotic factors took various forms. From short-standing stresses caused by deficiency of water during vegetation lasting several weeks, to highly onerous and long-standing droughts, which permanently damaged the water balance, and as a consequence, partially or totally damaged the tree stand. In numerous regions of Europe, there were similar reactions of plant communities on changes of pluvial conditions observed, whose consequences in the form of an intensified defoliation process, photosynthesis distortions, reduction of growth in thickness and a decrease in efficiency, became one of the most significant problems of forest management (Lasch et al. 1999, Klein-Tank and Können 2003; Schröter et al. 2005; Bréda et al. 2006; Costa and Soares 2008; Bolte et al. 2009). This state of affairs caused that currently, the main attention of foresters is focused first of all on hydrometeorological notions, connected with water balance of the forest, changes in the system of water retention and protection against effects of long-stand- ing droughts. Participants of the project of forests protection in Europe - MPOLE - draw attention to the crucial role of water management in the process of adaptation of forests to the climatic changes. Signatories of the project recommend improvement of previous, and where necessary, establishment of new concepts of managing water and forest resources on the basis of scenarios that consider future climate changes (Dubicki and Woźniak 1993; Pierzgalski and Tyszka 2005; Van Dijk and Keenan 2007; Odgen and Innes 2009; Durło 2012b).

Single-species spruce stands that dominate within the area of Silesian Beskid, are treated as ecosystems prone to distortions, where it is possible to use the resources in on long-term basis; however, preservation of their stability requires carefulness and significant investments in protection. Walters and Hooling (1990) suggest application of so-called adaptive management, consisting of realisation of a chosen concept of stability and periodic verification of parameters that determine the health condition of forests. This periodic verification ought to be performed through constant monitoring in the spheres of elevated risk of damages (Bodin and Wiman 2007). In turn, Barszcz et al. (2009) draw attention to the necessity of executing the periodic control of health condition of tree stands on the basis of an algorithm developed by Majterkierwicz, taking into account parameters of stability, among others, supply of the tree stand, tightness and tree planting as well as the indicator of reforestation. Schröter et al. (2005) believe that there is a need to focus on monitoring the main factors that endanger durability of forests through introduction of special monitoring zones. Currently, there are seven such zones operating in the Silesian Beskid, within which the monitoring of water balance of forest ecosystems is realised. There are also regular observations performed in that objects, regarding condition of trees leafage. An example of one of the above-mentioned concepts in a reference surface called peak parts of Barania mountain, is located in the Wisła and Węgierska Górka forest division. It was established in order to monitor differences in the course of processes of reforestation on post-disaster areas, in various variants of breeding conduct. Foresters are also supported by the regional system of meteorological protection, started in autumn 2012, based on monitoring of precipitation within the biggest drainage basin of the Silesian Beskid. Current data and reports from those systems can be found on lkpmeteo.pl website. Supervision over the system is 
currently performed by forest faculty of Agricultural University of Cracow.

\section{Conclusions}

The observed climate changes take place under influence of natural and anthropogenic causes that result in current parameters of distribution of separate meteorological phenomena. Weather phenomena, especially of dynamic course may lead to destabilisation of even correctly formed and properly developed forest ecosystem, and as a consequence, disturb balance in the natural environment. High frequency of extreme phenomena may cause total decay of a tree stand, independently from activity of other disease factors, such as fungal pathogens or insects.

1. A decrease of the indicator of precipitation volume may in the future turn out to be one of the major causes limiting presence of spruce in tree stands of lower subalpine level in the Silesian Beskid. A dangerous boundary, when distortions of water management may take place is $3.2 \mathrm{~mm} \cdot$ day $^{-1}$ per month. Going beyond this threshold significantly increases the risk of lowering health condition of spruce stands, independently from location and orographic conditions. In recent years, the probability of appearance of such a result elevated and currently remains on the level of $10 \%$.

2. The proportion between precipitation in summer and in winter is constantly deteriorating in relation to the warm part of the year, which is confirmed both by Schmuck moisture indicator and the indicator of habitat dryness by Vogel-Daniels, indexes that have reached a critically low level in recent years. Deficiency of precipitation in the period of June-August poses serious threat for the health condition of trees in the lower subalpine level of Silesian Beskid.

3. In the spruce stands of older age classes, more than 120 years, a total indicator of the surface of trees reached values, which would significantly influence the amount of water reaching the forest bottom. Too high tree planting caused that at precipitation on the level between 2 and $5 \mathrm{~mm}$ per day, water did not reach the forest soil. It happened that there was no precipitation registered under the tree crowns, even if it reached $7 \mathrm{~mm} / 24 \mathrm{~h}$ on an open space.
4. Heavy rains and microbursts with efficiency coefficient between 5.0 and 7.0, pose a serious threat to stability of ground, especially in the region of those fragments of slopes, where total decay of spruce stands took place in the Silesian Beskid, the probability of their appearance remains on the level of more than $20 \%$.

5. Within 60 years in the Silesian Beskid, there were more than 20 extreme weather (precipitation) episodes recorded, with various courses, intensity and surface reach, out of which at least 9 played a significant role in decreasing the health condition of trees, and as a consequence, influenced destabilisation of spruce stands, in various age classes and within various habitats. Taking into account that some of those phenomena resulted in an increased activity of biotic infective factors, it can be stated with complete certainty that pluvial conditions played a significant role within the course of a systemic disease of forests in the Silesian Beskid.

\section{Acknowledgement}

The present research was funded by the Grant No. NSC-2011/01/B/NZ9/04615 The impact of deforestation caused by the ecological disaster on spatial variations and changes in the chemistry of spring water and surface water in the Silesian Beskid.

\section{References}

Archaux F., Volters V. 2006. Impact of summer drought on forest biodiversity, what do we know? Annales Forest Science, 63, 645-652.

Barszcz J., Małek S. 2008. Stability of the Norway spruce (Picea abies [L.] Karst.) stands in the Silesian Beskid and Żywiecki Beskid Mountains from the aspect of their nutrition status. Journal of Forest Science, 54 (2), 41-48.

Barszcz J., Małek S., Majsterkiewicz K. 2009. Dynamics of changes in the risk the spruce forest collapse of the Silesian and Żywiecki Beskids. In.: The problems of spruce forest decay in Silesian and Żywiecki Beskids (eds.: J. Staszyk), (in Polish with English summary). PAN Publishing, Cracow, Poland, 93-113. 
Bąkowski R., Piotrowicz K. 2007. Selected cases of severe weather events in Poland in recent years. In.: Extreme hydrological and meteorological events (eds.: E. Bogdanowicz, U. Kossowska-Cezak, J. Szkutnicki), (in Polish with English summary). IMGW Publishing, Warsaw, Poland, 325-335.

Bodin P., Wiman B. 2007. The usefulness of stability concepts in forest management when coping with increasing climate uncertainties. Forest Ecology and Management, 242, 541-552.

Bolte A., Ammer C., Löf M., Madsen P., Nabuurs G.J., Schall P., Spathelf P., Rock J. 2009. Adaptive forest management in central Europe: Climate change impacts, strategies and integrative concept. Scandinavian Journal of Forest Research, 24 (6), 473-482.

Bréda N,, Huc R., Granier A., Dreyer E. 2006. Temperate forest trees and stands under severe drought: a review of ecophysiological responses, adaptation processes and long-term consequences. Annales Forest Science, 65 (6), 625-644.

Cebulak E., Niedźwiedź T. 1998. Extreme pulvial events in the upper basin of the Vistula, in 1995-1996 years. In.: Geonorphological and sedymentological record of local downpour (eds.: L. Starkel), (in Polish with English summary). Dokumentacja Geograficzna, 11 (1), 11-30.

Chomicz K. 1951. The downpurs and havy rains in Poland (in Polish with English summary). Wiadomości Stużby Hydrologicznej i Meteorologicznej, 2, (3), 5-88.

Costa A.C., Soares A. 2008. Trends in extreme precipitation indices derived from a daily rainfall database for the South of Portugal. International Journal of Climatology, 29 (13), 1956-1975.

Dubicki A., Woźniak Z. 1993. The impact of forest degradation of the environment in the Western Sudetes on the changing tide of mountain rivers (in Polish with English summary). Zeszyty Naukowe Akademii Rolniczej we Wroctawiu, Inżynieria Środowiska, 232 (III), 77-85.

Dubrovsky M., Nermesova I., Kalvova J. 2005. Uncertainties in climate change scenarios for The Czech Republic. Climate Resources, 29, 139-156.

Durło G. 2010a. Forest vegetation perion in Forest Promotional Complex in Silesian Beskid (in Polish with English sumary). Sylwan, 154 (8), 577-584.
Durło G. 2010b. The influence of pluvial conditions on spruce forest stands stability in Beskid Śląski Mountain. Acta Agrophisica, 184, 208-217.

Durło G. 2011. Spruce stands adaptability to climate change in Silesian Beskid (in Polish with English summary). Prace i Studia Geograficzne, 47, 227-236.

Durło G. 2012a. Climate of Silesian Beskid. (in Polish with English summary). Drukrol Publishing, Cracow, Poland, pp. 221.

Durło G. 2012b. The Impact of observed and predicted Climate conditions on The stability of mountain Forest stands in The Silesian Beskid (in Polish with English summary). Agricultural University in Cracow Publishing, Cracow, Poland, pp. 163.

Durský J., Škvarenina J., Minćáš J., Miková A. 2006. Regional analysis of climate change impact on Norway spruce (Picea abies L. Karst.) growth in Slovak mountain forests. Journal of Forest Science, 52, 306-315.

Feliksik E., Durło G. 2004. Climatological characteristic of the area of the Carpathian Regional Gene Bank in the Wisła Forest District. Dendrobiology, 51, 43-51.

Gregorič G., Niemeyer S. 2012. Drought indices in Europe. DMCSEE session foreseen for BALWOIS conference. Orchid, Macedonia, http://balwois. com/conference-/balwois-2012.

Holuša J. 2004. Health condition of Norway spruce [Picea abies (L.) Karst] stands in the Beskid Mts. Dendrobiology, 51, 7-11.

Klein Tank A.M., Können G.P. 2003. Trends in indices of daily temperature and precipitation extremes in Europe, 1946-99. Journal of Climate, 16 (22), 3665-3681.

Kondracki J. 1980. Physical geography of Poland (in Polish with English summary). PWN Publishing, Warsaw, Poland, pp. 463.

Kozak J., Troll M., Widacki W. 1999. Degradation of forest stands. In: Transformation of the natural environment the western part of the Beskid Mountains under the influence of anthropogenic impact (eds.: W. Widacki), (in Polish with English summary). Instytut Geografii Uniwersytetu Jagiellońskiego Publishing, Cracow, Poland, 33-84.

Lauscher F. 1976. Methoden zur weltklimatologie der hydrometeore. Der anteil des festen niederschlags 
am gesamptniederschlag: Achives fur Meteorologie, Geophisic und Bioklimatologie, 24, 129-176.

Lasch P., Lindner M., Ebert B., Flechsig M., Gerstengarbe F-W., Suckow F., Werner P.C. 1999. Regional impact analysis of climate change on natural and managed forests in the Federal State of Brandenburg, Germany. Environmental Modelling Assessment, 4, 273-286.

Luszniewicz A., Słaby T. 2003. Statistics package STATISTICA PL, theory and application. Academia Oeconomica (in Polish with English summary). Beck Publishing, Warsaw, Poland, pp. 445.

Majewski G., Przewoźniczuk W., Kleniewska M. 2010. Pluvial conditions on the Ursynow weather station in the years 1960-2009 (in Polish with English summary). Przeglad Naukowy - Inżynieria i Ksztaltowanie Środowiska, 2, 3-22.

Małek S. 2010. Nutrient fluxes in planted Norway Spruce stands of different age in southern Poland. Water, Air and Soil Pollution, 209, 45-59.

Migała K. 2005. The climate floors in the European mountains and the problem of global change (in Polish with English summary). Studia Geograficzne, 78, Wrocław, Poland, pp. 149.

Młynarczyk A., Sabor J. Banach J, Rozkowski R. 2011. Evaluation of genetic resources of Istebnian spruce on the conservative surfaces in situ and ex situ (in Polish with English summary). Sylwan, 155 (10), 674-686.

Modrzyński J. 1998. An outline of the spruce ecology. In.: The Spruce biology (eds.: A. Boratyński, W. Bugała) (in Polish with English summary). Bogucki Publishing, Poznań, Poland, 303-359.

Myczkowski J. 1978. The physiology of woody plants (in Polish with English Sumary). Agricultural Uniwersity in Cracow Publisher, Cracow, Poland, pp. 266.

Obmiński Z. 1977. The general outline of ecology. In.: The spruce (eds.: S. Białobok), (in Polish with English summary). Polish Academy of Science Monographs, 5, 332-371.

Ogden A.E., Innes J.L. 2009. Adapting to climate change in the boreal forest: locally identified research and monitoring needs to support decisionmaking on sustainable forest management. Arctic, 62 (2), 159-174.
Okołowicz W., Martyn D. 1979. Climatic regions in Poland. In.: Geographical atlas (in Polish with English summary). PPWK Publisher, Warsaw, Poland, pp. 11.

Pierzgalski E., Tyszka J. 2005. Water outflow during drought years from watersheds with various forest cover. Annals of WAU-Land Reclamation, 36, 21-28.

Rykowski K. 2003. The influence of Climate change on forest management. In.: Is Poland threatening climate catastrophe? (eds. M. Gutry-Korycka). Elipsa Publishing, Warsaw, Poland, 82-94.

Socha J., Durło G. 2012. How will Climate change impast biomass increment by Nowary Spruce stands in Western Beskids? Folia Forestalia Polonica, 54 (2), 94-108.

Styszyńska A. 2002. Relationships between Warta river flow in Poznan and winter NAO indices, in the period 1865-2000. In: North Atlantic Oscillation and its role in shaping climate and hydrologic variability in Polish. (eds.: A. Marsz, A. Styczyńska), (in Polish with English summary). Akademia Morska w Gdynii Publishing, 173-180.

Szabla K. 2009. Current status of spruce forest stands in Beskids and their genesis. In.: The problems of spruce forest decay in Silesian and Żywiecki Beskids (eds.: J. Starzyk), (in Polish with English summary). PAN Publisher, Cracow, Poland, 13-44.

Szabla K. 2011. The economic consequences of natural disasters in the forest stands. In.: Actual problems of forest economics (eds.: S. Zając), (in Polish with English summary). PTL Publishing, Warsaw, Poland, 265-302.

Troll M. 1995. Degradation of forest in Skrzyczne Massiff (Silesian Beskid) and its relationship to the land orography (in Polish with English summary). Sylwan 139 (7), 87-91.

Walters C.J., Holling, C.S. 1990. Large-scale management experiments and learning by doing. Ecology, 71 (6), 2060-2068.

Wiszniewski W., Chełchowski W. 1975. The climate characteristic and climate-forestry regionalization of Poland (in Polish with English summary). WKiE Publishing, Warsaw, Poland, pp. 36.

Van Dijk A.I., Keenan R.J. 2007. Planted forests and water in perspective. Forest Ecology and Management, 251, 1-10. 